\title{
Justina Sipavičiūtè
}

Instytut Historii Litwy

\section{Pieczęcie sądów ziemskich w Wielkim Księstwie Litewskim w latach 1564-1792}

\begin{abstract}
Zarys treści
W artykule rozpatrywane są pieczęcie sądów ziemskich i ich urzędników w WKL (w dziewięciu powiatach województw wileńskiego i trockiego) w latach 1564-1792. Materiał empiryczny do badań stanowiło około dwustu niepublikowanych pieczęci sądów ziemskich i ich urzędników. Artykuł dzieli się na trzy części. Część pierwsza zawiera analizę sposobu określania w statutach litewskich i Volumina legum zasad używania pieczęci sądów ziemskich i ich urzędników oraz realizowania tego w praktyce. W części drugiej pieczęcie sądów ziemskich zbadano pod względem heraldycznym i sfragistycznym. Takiej samej analizie w części trzeciej poddano pieczęcie urzędników sądów ziemskich - sędziów i podsędków. W artykule postawiono tezę, że zawarte w II Statucie litewskim z 1566 r. i trzecim z 1588 r. oraz wprowadzone w ramach reformy z 1764 r. normy określające używanie pieczęci sądów ziemskich i ich urzędników były przestrzegane.
\end{abstract}

\begin{abstract}
The article deals with seals of land courts and their officials in the Grand Duchy of Lithuania (in nine districts of the Wilno (Vilnius) and Troki (Trakai) voivodeships) in 1564-1792. The study is based about two hundred unpublished seals of land courts and their officials. The article is divided into three parts: part one presents an analysis of how the use of seals by land courts and officials was described in the Statutes of Lithuania and the Volumina legum, and in what way those regulations were implemented in practice. Part two is devoted to a thorough heraldic and sphragistic analysis of the seals of land courts, and part three - to an analysis of land court officials: judges, and sub-judges (singular: podsędek, subiudex). The article puts forward the thesis that the norms included in the Second (1566) and Third (1588) Lithuanian Statutes, and those introduced by the reform of 1764, regulating the use of seals of land courts and of their officials were abided by. The article is supplemented by an annexe with the photographs of seals of land courts and their officials.
\end{abstract}

Słowa kluczowe: pieczęć, tłok pieczętny, heraldyka, statuty litewskie, sąd ziemski

Keywords: seal, stamp, heraldry, Lithuanian Statutes, land court 


\section{Wprowadzenie}

Prawo pieczętne i same pieczęcie ${ }^{1} \mathrm{w}$ każdym państwie i w różnych okresach historycznych były odmienne ${ }^{2}$. Wyjątku nie stanowiło również Wielkie Księstwo Litewskie. XVI stulecie zasługuje na miano wieku reform. Jedna z głównych wprowadzonych w tym stuleciu - w latach 1564-1566 - reform dotyczyła sądownictwa i administracji. Również na początku XVI w. - w 1529 r. - ukazał się I Statut litewski, po upływie 37 lat - w 1566 r. - zastąpił go II Statut litewski, ustępując miejsca kilkadziesiąt lat później, w 1588 r., III Statutowi litewskiemu. W I Statucie litewskim z 1529 r. znajdujemy tylko kilka artykułów poświęconych pieczęciom i dopiero w II Statucie z 1566 r. po raz pierwszy szczegółowo opisane zostało używanie pieczęci w Wielkim Księstwie ${ }^{3}$.Zarówno w II, jak i w uchwalonym kilka dziesięcioleci później III Statucie litewskim ${ }^{4}$ znajdujemy już wiele artykułów z opisem używania pieczęci. Dzielą się one na trzy grupy: pieczęcie władców, sądów państwowych i prywatne ${ }^{5}$. Różny stopień zaawansowania badań nie pozwala na dokonanie wszechstronnej analizy wszystkich pieczęci, skupię się więc i ograniczę tylko do jednego z sądów państwowych - ziemskiego i używanych w nim pieczęci.

Powstało wiele publikacji zawierających wyniki ważnych badań dotyczących litewskich sądów ziemskich ${ }^{6}$, jednakże pieczęci tych sądów i ich urzędników nie

\footnotetext{
${ }^{1}$ W historiografii naukowej funkcjonują dwa pojęcia: pieczęci (sigillum, das Siegel, neuamb) i tłoku pieczętnego (der Siegelstempel, das Petschaft, umamn) lub po prostu tłoku. Tłok jest narzędziem do odciskania pieczęci, pieczęć zaś to to, co jest tłokiem odciśnięte; E. Rimša, Pieczęcie miast Wielkiego Księstwa Litewskiego, tłum. J. Sienkiewicz, Warszawa 2007, s. 59-81, 82-172.

${ }^{2}$ Więcej o rozwoju prawa pieczętnego w starożytności, średniowieczu i czasach nowożytnych zob.: G.A. Seyler, Geschichte der Siegel, Leipzig 1894, s. 52-55; Th. Ilgen, Sphragistik, w: Grundriß der Geschichtswissenschaft, t. 1, cz. 4, red. A. Meister, Leipzig-Berlin 1912, s. 49-57; W. Ewald, Siegelkunde, München-Berlin 1914, s. 27-51; M. Gumowski, M. Haisig, S. Mikucki, Sfragistyka, Warszawa 1960, s. 60-71; E. Kittel, Siegel, Braunschweig 1970, s. 7-131; Н.А. Соболева, Русские печати, Москва 1991, s. 26-69; A. Stieldorf, Siegelkunde, Hannover 2004, s. 37-54.

${ }^{3}$ Pirmasis Lietuvos Statutas, t. 2, cz. 1: Tekstai senaja baltarusiu, lotynu ir senaja lenku kalbomis, wyd. S. Lazutka et al., Vilnius 1991; I. Valikonyte, S. Lazutka, E. Gudavičius, Pirmasis Lietuvos Statutas (1529 m.), Vilnius 2001; Statut Litewski drugiej redakcyi (1566), w: Pomniki prawa litewskiego z XVI wieku, wyd. F. Piekosiński, Kraków 1900 (Archiwum Komisyi Prawniczej, t. 7); Cmamym Вялікага княства Літоўскага 1566 года, wyd. Т.I. Даўнар et al., Мінск 2003.

${ }^{4}$ J. Lappo, 1588 m. Lietuvos Statutas, t. 2: Tekstas, Kaunas 1938.

${ }^{5}$ Te grupy możemy wydzielić tylko w Statutach litewskich, jednak, jak zaznacza najwybitniejszy znawca sfragistyki i heraldyki litewskiej, historyk Edmundas Rimša, w Wielkim Księstwie własne pieczęcie mieli też władcy, szlachta, różne instytucje państwowe i kościelne, sądy, Uniwersytet Wileński, miasta, cechy, bractwa, gildie, mieszczanie, duchowni etc. Dogłębne badania tego zagadnienia zostały już podjęte, nadal jednak wiele szczegółowych kwestii wymaga zbadania; zob. np.: E. Rimša, Pieczęcie miast Wielkiego Księstwa Litewskiego...; idem, Lietuvos didžiojo kunigaikščio Vytauto antspaudai ir žemių heraldika, Vilnius 2016 i in.

${ }^{6}$ Więcej o sądach ziemskich zob.: И. Лаппо Земский суд в Великом Княжестве Литовском в конце XVI века, С.-Петербург 1897, s. 263-301; М. Любавский, Литовско-русский сейм,
} 
zostały jeszcze szczegółowo zbadane. Problematykę pieczęci używanych w sądach ziemskich wskazywano w historiografii jako zjawisko wymagające osobnych badań, jednak nie doczekało się ono zadowalających wyników. Pierwsze prace w tej materii ogłosili jeszcze w XIX w. Michał Baliński ${ }^{7}$, Aleksiej Sapunow ${ }^{8}$ i Czesław Jankowski ${ }^{9}$, jednak pieczęcie sądów ziemskich nie były w ich książkach analizowane, a jedynie wykorzystywane jako ilustracje w tekście. Podobną funkcję pełniły pieczęcie sądów ziemskich również w pracach późniejszych autorów: Józefa Jodkowskiego $^{10}$, Ottona Hedemanna ${ }^{11}$, Mariana Gumowskiego ${ }^{12}$, Anatolija Citowa ${ }^{13}$, Juozasa Galkusa ${ }^{14}$ i Alaksieja Szałandy ${ }^{15}$. Gumowski ${ }^{16}$ jako jeden z pierwszych zauważył obecność na pieczęciach litewskich sądów ziemskich godła państwowego, nie analizował ich jednak bardziej szczegółowo i nie podał odsyłaczy do archiwaliów. Tym niemniej w ostatnim dwudziestoleciu ukazało się kilka ważnych publikacji, przynoszących nowe dane o pieczęciach sądów ziemskich Litwy. Citow ${ }^{17} \mathrm{np}$. analizował normy statutów litewskich określające używanie pieczęci sądów ziemskich, poddał jednak analizie nie wszystkie owe normy, jak również nie wskazał, których z nich przestrzegano w praktyce. Pieczęcie koronnych sądów ziemskich dogłębnie i wieloaspektowo badał Marek Adamczewski ${ }^{18}$, podając przy tym odsyłacze do źródeł z pieczęciami sądów ziemskich Wielkiego Księstwa. Choć pieczęciom litewskim nie poświęcił szczególnej uwagi, to jego praca ma istotne znaczenie dla przyszłych badaczy, dzięki niej można będzie bowiem badać wpływ pieczęci używanych w koronnych sądach ziemskich na

Москва 1900, s. 721-724; И. Лаппо, Великое Княжество Литовское за время от заключения Люблинской Унии до смерти Стефана Батория (1569-1586), сz. 1, С.-Петербург 1901, s. 352-354; idem, Великое Княжество Литовское во второй половине XVI столетия. Литовско-русский повет и его сеймик, Юрьев 1911, s. 498-523; D. Vilimas, Lietuvos Didžiosios Kunigaikštystès žemès teismo sistemos formavimasis (1564-1588), Vilnius 2006.

${ }^{7}$ M. Baliński, Historya miasta Wilna, t. 2, Wilno 1836, s. 65.

${ }^{8}$ А.П. Сапунов, Витебская старина, t. 1, Витебск 1883, zob. wklejkę przed s. 1.

${ }^{9}$ C. Jankowski, Powiat oszmiański. Materjały do dziejów ziemi i ludzi, cz. 1, Petersburg 1896, s. 164.

${ }^{10}$ J. Jodkowski, Pieczęcie polskie w muzeum Rumiancowskiem w Moskwie, „,Wiadomości Numizmatyczno-Archeologiczne" 2, 1910, nr 6, s. 95.

11 O. Hedemann, Historja powiatu brasławskiego, Wilno 1930, s. 341.

${ }_{12}$ M. Gumowski, Handbuch der polnischen Siegelkunde, Graz 1966, s. 119.

${ }^{13}$ А. Цитоу, Геральдикыка Беларуси, Минск 2007, s. 22, 96, 98, 99, 100.

${ }^{14}$ J. Galkus, Lietuvos Vytis, Vilnius 2009, s. 206.

15 А. Шаланда, Геральдыка Валовічаў XVI-XVIII стст. Мифы ірэальнасцьь, w: Unus pro omnibus. Валовічы у гісторыі Вялікага княства Литоўскага XV-XVIII cmст., орrac. А.М. Янушкевіч, red. А.І. Шаланда, Мінск 2014, s. 169.

${ }^{16}$ M. Gumowski, M. Haisig, S. Mikucki, op. cit., s. 254-255.

${ }^{17}$ А. Цитоу, Пячатки старажытнай Беларуси. Нарысы сфрагистыки, Минск 1993, s. 25, 113-118; idem, Сфрагистыка и Геральдикыка Беларуси, Минск 1999, na s. 44, 46, 47-48 też zdjęcia pieczęci sądów ziemskich.

${ }^{18}$ M. Adamczewski, Pieczęcie urzędowe władz lokalnych z obszaru Polski centralnej, Łódź 2010, s. 62, $64,65,83$. 
heraldykę analogicznych pieczęci litewskich. Najbardziej wyczerpująco analizuje problem artykuł Szałandy ${ }^{19}$ o pieczęciach litewskich sądów ziemskich, zawierający genezę pieczęci sądów ziemskich oraz ich klasyfikację według heraldyki przedstawienia napieczętnego. Przeglądowy charakter prac powodował, że historycy ograniczyli się do prezentacji pieczęci sądów ziemskich, niewiele uwagi poświęcając używanym również pieczęciom urzędników tychże sądów ${ }^{20}$. Rodzi się zatem wiele pytań, na które historiografia nie udzieliła jeszcze odpowiedzi. Celem tego artykułu jest przede wszystkim zbadanie norm statutów litewskich i Volumina legum określających używanie pieczęci sądów ziemskich i ich urzędników, wraz $\mathrm{z}$ tym, co jest bodaj ważniejsze, czyli sposobem realizacji tych norm w praktyce, by określić, czy były one w ogóle przestrzegane. Następnie zaś zostanie przeprowadzona analiza heraldyczna i sfragistyczna pieczęci sądów ziemskich i ich urzędników w województwach wileńskim i trockim. Pozwoli to ustalić: co, dlaczego i jak przedstawiano na tych pieczęciach.

W trakcie prowadzonych badań wykorzystano źródła zarówno publikowane, jak i pozostające jeszcze w rękopisie, przechowywane w zbiorach bibliotecznych i archiwalnych. Źródła publikowane to statuty litewskie z lat 1529, 1566 i 1588²1, Volumina legum ${ }^{22}$ i akty sądowe ${ }^{23}$. Spośród źródeł niepublikowanych ${ }^{24}$ wymie- $^{2}$ nić należy około stu pieczęci sądów ziemskich i ponad sto pieczęci urzędników sądów ziemskich - sędziów i podsędków - województw wileńskiego i trockiego ${ }^{25}$

${ }^{19}$ А. Шаланда, Земскія печаткі Вялікага Княства Літоўскаго у XVI-XVIII cm. Аснаўныя mыпьы, „Сфрагистичний щорічник” 4, 2013, s. 277-298.

${ }^{20} \mathrm{Z}$ interesujących dla opisywanego zagadnienia prac zob.: О. Алфьоров, О. Однороженко, Українські особові печатки XV-XVII ст. За матеріалами київських архивосховищ, Харків 2008; Г. Семянчук, Агульнае и асабівае у шляхецкай геральдыщы Гарадзенскага павета другой паловы XVI-пачатку XVII cm., „Сфрагистичний щорічник” 4, 2013, s. 428-429; А. Цитоу, Пячатки старажытнай Беларуси..., s. 43, 46, 74, 75, 82, 88, 90, 91; idem, Геральдыкка Беларуси..., s. 10; idem, Сфрагистыка и Геральдыка Беларуси..., s. 44-45; А. Шаланда, Земскія печаткі..., s. 284. Do zbadania pozostaje kwestia, czy urzędnicy sądów ziemskich pieczętowali prywatne dokumenty tymi samymi tłokami, których używali w sądach ziemskich.

${ }^{21}$ Pirmasis Lietuvos Statutas..., t. 2, cz. 1; I. Valikonyte, S. Lazutka, E. Gudavičius, Pirmasis Lietuvos Statutas...; Statut Litewski drugiej redakcyi...; Cтатут Вялікага княства Літоўскага 1566...; J. Lappo, op. cit., t. 2.

22 Volumina legum, t. 7: Ab anno 1764 ad annum 1768, wyd. J. Ohryzko, Petersburg 1860.

${ }^{23}$ Акты, издаваемые Виленскою комиссиею для разбора древних актов, t. 22: Акты Слонимского земского суда, Вильна 1895.

${ }^{24}$ Materiał badawczy stanowiło około dwustu niepublikowanych pieczęci sądów ziemskich i ich urzędników. Zostały one wybrane z wypisów z ksiąg sądów ziemskich, ich wyroków, pozwów i innych dokumentów. Nie ma specjalnych zbiorów, w których byłyby przechowywane dokumenty sądów ziemskich i ich urzędników. Dokumenty z pieczęciami można znaleźć w najróżniejszych zbiorach poszczególnych osób, familii, instytucji i in. Jest to grupa źródeł godna zaufania, ukazująca, jak normy określające używanie pieczęci sądów ziemskich i ich urzędników były przestrzegane w praktyce.

${ }^{25}$ Choć w niniejszym artykule analizowane są tylko pieczęcie sądów ziemskich województw wileńskiego i trockiego, czyli dziewięciu powiatów, prowadzone obecnie badania źródeł archiwalnych 
z okresu od drugiej połowy XVI do drugiej połowy XVIII w. Ramy chronologiczne artykułu obejmują okres od lat 1564-1566 do 1792 r., czyli od pojawienia się sądów ziemskich do ich likwidacji.

\section{Formalnoprawne normy używania pieczęci w sądach ziemskich i poziom ich realizacji}

Utworzone w latach 1564-1566 w każdym powiecie sądy ziemskie nie tylko rozpatrywały sprawy cywilne, ale też pełniły funkcje notarialne ${ }^{26}$. Ich działalność nie stanowiła czynności ciągłej. Sądy zbierały się na sesje trzy razy do roku. Sąd ziemski składał się z sędziego, podsędka i pisarza ${ }^{27}$. Każdy sąd ziemski miał też swój tłok, zalecony w II Statucie litewskim z $1566 \mathrm{r}^{28}$

Art. 10 rozdz. 4 II Statutu litewskiego ${ }^{29}$ nakazuje, by sąd ziemski miał tłoki pieczętne dwóch rodzajów. Pierwszy to tłok sądu ziemskiego, który przedstawiać

pozwalają na sformułowanie ostrożnej hipotezy, że podobne tendencje występowały w XVI-XVIII w. również $\mathrm{w}$ innych województwach Litwy. To jednak wymaga jeszcze weryfikacji i dodatkowych analiz źródłowych.

${ }^{26}$ Nie można uznać, że powiatowy sąd ziemski był nudnym urzędem notarialnym. Przeglądając księgi sądów ziemskich, można napotkać tego samego szlachcica zarówno w roli ofiary, jak i przestępcy, a niektóre osoby występowały na tej samej sesji sądowej w kilku czy nawet kilkunastu sprawach. Więcej o notarialnych funkcjach sądów zob.: D. Vilimas, LDK pavieto Žemés teismy funkcija - tarp notariato ir teismo (iki 1588 m.) (lietuvišku pavietu atvejis), „Lituanistica” 57, 2011, nr 4(86), s. 355-364; idem, Lietuvos Didžiosios Kunigaikštystès žemès teismo..., s. 90-91, 104; idem, Kauno žemés teismas paskutiniaisiais Stepono Batoro valdymo metais, „Lituanistica” 57, 2011, nr 3(85), s. 229-230.

27 Więcej o urzędnikach sądów ziemskich zob.: D. Vilimas, Lietuvos Didžiosios Kunigaikštystès žemès teismo..., s. 105-130; Urzędnicy Wielkiego Księstwa Litewskiego. Spisy, t. 1: Województwo wileńskie XIV-XVIII wiek, red. A. Rachuba, Warszawa 2004; Urzędnicy Wielkiego Księstwa Litewskiego. Spisy, t. 2: Województwo trockie XIV-XVIII wiek, red. A. Rachuba, Warszawa 2009.

${ }^{28}$ Najwcześniejsze wzmianki o tłokach pieczętnych sądów ziemskich znajdujemy w „prośbach” szlachty chcącej wprowadzenia takich sądów do Wielkiego Księstwa; А. Шаланда, Земскія печаткі..., s. 280-282. Tłoki sądów ziemskich są także wspominane w dokumentach o wydzielaniu powiatów, potwierdzających, że powiatowi udzielany jest tłok. Np. w dokumencie o wydzieleniu powiatu oszmiańskiego czytamy, że tłok zostanie doręczony przez posłańca królewskiego od razu po złożeniu przysięgi przez pisarza; D. Vilimas, Lietuvos Didžiosios Kunigaikštystės žemés teismo..., s. 81. Wreszcie na polecenie Zygmunta Augusta w 1565-1566 r. zostały sporządzone i przekazane pisarzom sądów ziemskich wszystkich powiatów tłoki z godłem państwowym; Актық..., t. 22: Акты Слонимского земского суда, s. 147. Choć przekazanie tłoków zostało odnotowane, nie sposób uzyskać więcej informacji na temat heraldyki tłoków sądów ziemskich. Wiemy tylko, że miały one być z godłem państwowym. Normy używania tłoków pieczętnych w sądach ziemskich zostały ustanowione dopiero w II Statucie litewskim.

${ }^{29}$ Statut Litewski drugiej redakcyi..., rozdz. 4, art. 10, s. 80-81; Статут Вялікага княства Лiтоўскага 1566..., s. 103. 
miał herb państwa ${ }^{30}$, a wokół niego zapisana miała być nazwa odnośnego powiatu (zob. il. 1) $)^{31}$. Tym tłokiem można było pieczętować tylko pozwy wydane w imieniu władcy ${ }^{32}$. Tłok miał przechowywać pisarz przysięgły. Drugim typem były tłoki urzędników sądu ziemskiego - sędziego i podsędka. Pieczętowano nimi wszystkie pozostałe dokumenty sądu ziemskiego, z wyjątkiem pozwów, a pisarz sądu ziemskiego miał je uwierzytelniać swoim podpisem (zob. il. 2 i 4). W art. 12 rozdz. 4 III Statutu litewskiego norma ta została powtórzona i potwierdzona ${ }^{33}$. Zebrane do badania pieczęcie pokazują, że przestrzegano tego zalecenia. Używanie dwóch tłoków - sądu ziemskiego i jego urzędników - trwało około 200 lat, aż do uchwalonej w 1764 r. przez sejm konwokacyjny konstytucji ${ }^{34}$.

Zanim przejdziemy do omówienia roli reformy z 1764 r., zwróćmy uwagę na jeszcze kilka norm ustanowionych w statutach II i III, a dotyczących używania pieczęci przez sądy ziemskie i ich urzędników oraz realizację tych norm. Na przykład statuty II i III wprowadzały opłaty za przystawienie pieczęci. Ich wysokość kształtowała się w różny sposób. Zależała od rodzaju przykładanej pieczęci, wagi dokumentu, materiału i innych rzeczy, w największym jednak stopniu od tego, kto dokument pieczętował ${ }^{35}$.

Art. 5 rozdz. 4 III Statutu litewskiego stanowił, że sędziemu trzeba zapłacić za pieczęć 4 gr, podsędkowi zaś o połowę mniej, tylko $2 \mathrm{gr}^{36}$. Jako że dokumenty

${ }^{30}$ Pogoń, lit. Vytis, dalej w artykule określana jest jako herb państwa; Z. Piech, Monety, pieczęcie $i$ herby $w$ systemie symboli władzy Jagiellonów, Warszawa 2003, s. 227-242; E. Rimša, Heraldry. Past to Present, tłum. V. Arbas, Vilnius 2005, s. 58-71; idem, The Heraldry of Lithuania, thum. V. Urbonavičius, D. Barnard, Vilnius 2008, s. 15-22; J. Galkus, op. cit.; E. Rimša, Lietuvos didžiojo kunigaikščio Vytauto..., s. 62.

${ }^{31}$ Np. pozew z 1568 r. z pieczęcią sądu ziemskiego w Kownie (B. Wróblewskich, RS, f. 38-1, k. 60v); wypis z ksiąg Trybunału Głównego Litewskiego w Wilnie z 1599 r. z pieczęcią sądu ziemskiego w Wilnie (B. Wróblewskich, RS, f. 264-797, k. 3v). W ruskim odpisie II Statutu litewskiego nie jest wskazane, że nazwa powiatu ma być pisana wokół herbu, tymczasem w jego odpisie łacińskim czytamy nie tylko, że nazwa powiatu ma być pisana wokół herbu, ale też że herb ma prezentować figurę zbrojnego jeźdźca; por. Statut Litewski drugiej redakcyi..., rozdz. 4, art. 10, s. 80-81; Статут Вялікага княства Літоўскага 1566..., s. 103. Problem odpisów II Statutu litewskiego wymaga osobnych badań w przyszłości; por. J. Bardach, Statuty litewskie a prawo rzymskie, Warszawa 1999, s. 54-56.

${ }^{32}$ Pozew sądu ziemskiego w Wilnie z 1568 r. z tytułem Zygmunta Augusta (B. Uniwersytetu Wileńskiego, RS, f. 69-112); pozew sądu ziemskiego w Upicie z 1581 r. z tytułem Stefana Batorego (LPAH, f. 1294, ap. 1, b. 19, k. 1).

${ }^{33} \mathrm{~W}$ artykule zostały wyszczególnione rodzaje dokumentów, które miały być pieczętowane tłokami urzędników; J. Lappo, op. cit., t. 2, rozdz. 4, art. 12, s. 180.

${ }^{34}$ R. Šmigelskytè-Stukienè, Lietuvos Didžiosios Kunigaikštystès pavieto teismu notarinès funkcijos, w: Lietuvos notariato istorija, red. J. Karpavičiene, Vilnius 2012, s. 79-80; R. Šmigelskytė-Stukiené, E. Brusokas, L. Glemža et al., Modernios administracijos tapsmas Lietuvoje. Valstybés institucijy raida 1764-1794 metais: kolektyvinè monografija, Vilnius 2014; Volumina legum..., t. 7, s. 178.

35 Th. Ilgen, op. cit., s. 29; W. Ewald, op. cit., s. 68-69; M. Gumowski, M. Haisig, S. Mikucki, op. cit., s. 84-85; Н.А. Соболева, op. cit., s. 56-57.

${ }^{36}$ J. Lappo, op. cit., t. 2, rozdz. 4, art. 5, s. 170-172. 
sądu ziemskiego wydawane przez sędziego i podsędka musiały mieć dwie pieczęcie, łączna suma opłaty wynosiła 6 gr. Art. 18 rozdz. 4 III Statutu litewskiego przewidywał, że pisarzowi za potwierdzenie pozwu napisanego przez stronę pieczęcią sądu ziemskiego należał się $1 \mathrm{gr}^{37}$. Trzeba podkreślić, że była to tylko opłata za pieczęćc ${ }^{38}$. Spisanie bowiem odpowiedniego dokumentu również kosztowało. W XVII-XVIII w. cena odciśnięcia pieczęci ulegała zmianom, brak jednak wiarygodnych źródeł potwierdzających uiszczanie tego typu opłat.

Ważnym aspektem funkcjonowania pieczęci sądów ziemskich jest ich podrabianie. W średniowieczu i czasach nowożytnych było ono kwalifikowane jako najcięższe przestępstwo, choć kary różniły się w zależności od kraju i okresu historycznego. Fałszerzy pieczęci skazywano na spalenie na stosie, powieszenie, wypalenie piętna hańby, więzienie, banicję ${ }^{39}$. Czasami fałszerzowi udawało się uniknąć kary dzięki zapłaceniu pewnej sumy pieniędzy, zależało to jednak od jego pozycji w społeczeństwie. W Wielkim Księstwie również przewidziano surowe kary za fałszowanie pieczęci i podrabianie tłoków. Art. 5 rozdz. 1 I Statutu litewskiego przewidywał za sfałszowanie dokumentu władcy lub podrobienie jego pieczęci karę spalenia na stosie ${ }^{40}$.

Art. 12 rozdz. 1 II Statutu litewskiego przewidywał, że za podrabianie dokumentów, pieczęci i podpisu władcy, jak też podpisów kanclerza i pisarzy Wielkiego Księstwa, wycinanie, przechowywanie i używanie tłoków pieczęci władcy grozi kara śmierci poprzez spalenie na stosie ${ }^{41}$. Za inne przestępstwa: fałszowanie dokumentów urzędowych i sądowych oraz poprawianie pieczęci, zdejmowanie $\mathrm{z}$ jednego dokumentu i doczepiania do innego, sfałszowanego, również groziła kara śmierci, jednak o paleniu na stosie już nie wspominano.

Art. 16 rozdz. 1 III Statutu litewskiego miał podobne brzmienie, ale był nieco rozszerzony ${ }^{42}$. Najważniejsze bodaj było $\mathrm{w}$ nim to, że za podrabianie tłoków pieczętnych nie tylko władcy, ale już i instytucji państwowych (w tym również

\footnotetext{
${ }^{37}$ Ibidem, rozdz. 4, art. 18, s. 186-187. Art. 18 rozdz. 4 III Statutu litewskiego przewidywał, że pisarz ma nie tylko przykładać przydzieloną powiatowi pieczęć, ale też składać na pozwach swój podpis. Odpowiedzialność pisarza wzrastała, ponieważ prócz pieczęci stawiał on swój podpis, czego nie wymagał II Statut litewski.

${ }^{38} \mathrm{~Np}$. na Litwie, w zależności od wielkości miasta i instytucji, w XVI w. odbiorca dokumentu musiał zapłacić za pieczęć od 1 do 3, w XVII - od 2 do 6 gr; E. Rimša, Pieczęcie miast Wielkiego Księstwa Litewskiego..., s. 195.

${ }^{39}$ Więcej o fałszerzach i karach za fałszerstwo zob.: Th. Ilgen, op. cit., s. 57-58; E. Kittel, op. cit., s. 141; G.A. Seyler, op. cit.., s. 52-55; W. Ewald, op. cit., s. 235; M. Gumowski, M. Haisig, S. Mikucki, op. cit., s. 118; A. Stieldorf, op. cit., s. 57-58; T. Diederich, Siegelkunde, Beiträge zu ihrer Vertiefung und Weiterführung, Böhlau-Wien 2012, s. 221-249.

${ }^{40}$ Pirmasis Lietuvos Statutas..., t. 2, cz. 1, rozdz. 1, art. 5, s. 68-69; I. Valikonyte, S. Lazutka, E. Gudavičius, Pirmasis Lietuvos Statutas..., s. 127.

${ }^{41}$ Statut Litewski drugiej redakcyi..., rozdz. 1, art. 12, s. 9; por. Статут Вялікага княства Літоусккага $1566 \ldots$, s. 56.

42 J. Lappo, op. cit., t. 2, rozdz. 1, art. 16, s. 82-83.
} 
sądów ziemskich) groziła kara spalenia na stosie. II Statut nie opisywał tego odrębnie $^{43}$. Tak jak w II Statucie, za fałszowanie zarówno pieczęci, jak i dokumentów urzędowych (a więc i sądów ziemskich) przewidziano karę śmierci. Palenia na stosie jednak nie przewidywano. Przewidziana kara była zatem bardzo surowa, dotychczas jednak nie odnaleziono źródłowego potwierdzenia stosowania w Wielkim Księstwie Litewskim kary śmierci poprzez spalenie na stosie za fałszowanie tłoków lub pieczęci ${ }^{44}$.

W statutach litewskich znajdujemy również artykuły określające zasady użycia pieczęci urzędników sądów ziemskich, ale nie ich heraldykę. Są to np. artykuły poświęcone przechowywaniu ksiąg sądu ziemskiego ${ }^{45}$, spisywaniu testamentó $\mathrm{w}^{46}$ oraz sporządzaniu wypisów z ksiąg podkomorzego po jego śmierci ${ }^{47}$.

Reforma z 1764 r. nie tylko zmieniła ustaloną strukturę kancelarii sądów ziemskich, ale i znacznie przekształciła tryb pieczętowania dokumentów. Wycofano

${ }^{43}$ Można przypuszczać, że w okresie ustanawiania II Statutu litewskiego sądy ziemskie dopiero się kształtowały, podczas gdy za III Statutu litewskiego tłoki sądów ziemskich funkcjonowały już od kilkudziesięciu lat. Mogły też być sprawy o fałszowanie tłoków pieczętnych. Kolejnym przypuszczeniem jest to, że tłoki sądów ziemskich miały godło państwowe, dlatego bardzo ważne było ustanowienie norm ich sporządzania i używania.

${ }^{44}$ W Wielkim Księstwie fałszerzom, nawet kiedy byli skazywani na karę śmierci lub żądano spalenia ich na stosie, udawało się tej kary uniknąć. Za fałszowanie tłoków i pieczęci ferowano kary łagodniejsze. Jedni musieli publicznie wykazać skruchę, niektórych wtrącano do więzienia, stosowano też inne kary; E. Rimša, Pieczęcie miast Wielkiego Księstwa Litewskiego..., s. 201-202. Więcej o fałszerzach w WKL zob.: А. Цитоу, Пячатки старажытнай Беларуси..., s. 163-166; R. Ragauskienè, Galimybès klastoti bajorijos dokumentus Lietuvos Didžiojoje Kunigaikštystėje XVI a., „Istorijos šaltinių tyrimai”, 1, 2008, s. 235; idem, Dingę istorijoje. XVI a. Lietuvos Didžiosios Kunigaikštystès privatūs archyvai, Vilnius 2015, s. 278

${ }^{45}$ Księgi sądu ziemskiego miały być złożone i przechowywane w mocnej skrzyni z trzema zamkami, do których jeden klucz miał sędzia, drugi - podsędek i trzeci - pisarz; w dodatku miała ona być opieczętowana ich pieczęciami; Statut Litewski drugiej redakcyi..., rozdz. 4, art. 11, s. 81-82; Статут Вялікага княства Літоўскага 1566..., s. 103; art. uzupełniony w: J. Lappo, op. cit., t. 2, rozdz. 4 , art. 13, s. 180-182.

${ }^{46}$ Art. 2 rozdz. 8 II Statutu litewskiego nakazywał, by przy spisywaniu testamentu obecni byli urzędnicy sądu ziemskiego (sędzia, podsędek, pisarz) i ksiądz. Jeśli urzędnicy nie mogą być przy tym obecni, testament może być spisany w obecności trzech godnych zaufania osób świeckich; Statut Litewski drugiej redakcyi..., rozdz. 8, art. 2, s. 165-166; Статут Вялікага княства Літоўскага 1566..., s. 158-159. Art. 2 rozdz. 8 III Statutu litewskiego był jeszcze bardziej szczegółowy. W spisywaniu testamentu mieli uczestniczyć urzędnicy sądu ziemskiego lub grodzkiego tego powiatu, w którym testament sporządzano, ale jeżeli z sądu ziemskiego lub grodzkiego stawił się tylko jeden urzędnik, mogły obok niego wystąpić dwie osoby ze szlachty. Jeżeli nie było ani jednego urzędnika, testament mogły potwierdzić trzy godne zaufania osoby ze szlachty, osiadłe w Wielkim Księstwie Litewskim. Artykuł nakazywał także, by zarówno spisujący testament, jak i świadkowie, o ile są piśmienni, złożyli podpisy; J. Lappo, op. cit., t. 2, rozdz. 8, art. 2, s. 338-340.

${ }^{47}$ Po śmierci podkomorzego wypisy z ksiąg podkomorskich miały być wydawane z pieczęciami sędziego i podsędka oraz podpisem pisarza sądu ziemskiego; J. Lappo, op. cit., t. 2, rozdz. 9, art. 9, s. 355. 
wówczas z użytku tłoki pieczętne urzędników sądu ziemskiego - sędziego i podsędka. W każdym powiatowym sądzie ziemskim był jeden tłok sądu ziemskiego, którym uwierzytelniano już wszystkie rodzaje dokumentów tego sądu (zob. il. 3) ${ }^{48}$.

Sejm Czteroletni wprowadził nowy podział administracyjny całego państwa i przekształcił funkcjonujący od XVI w. system sądownictwa: zniósł powiatowe sądy grodzkie, ziemskie i podkomorskie, a w ich miejsce wprowadził nowe instytucje. 10 stycznia 1792 r. uchwalona została ustawa o powołaniu w miejsce likwidowanych sądów ziemskich i grodzkich - powiatowych sądów ziemiańskich ${ }^{49}$. Używały one też nowych, sporządzonych dla nich tłoków ${ }^{50}$.

\section{Pieczęcie sądów ziemskich}

Przejdźmy teraz do kolejnego zagadnienia - heraldyki pieczęci sądów ziemskich w latach 1564-1792. Pieczęcie sądów ziemskich były najczęściej odciskane ${ }^{51}$. Jeśli chodzi o ich rozmiar, to widoczna była tendencja wzrostowa. W drugiej połowie XVI w. ich średnica nie osiągała $30 \mathrm{~mm}$, podczas gdy w XVIII w. była aż dwukrotnie większa ${ }^{52}$.

${ }^{48}$ Volumina legum..., t. 7, s. 178. Po 1764 r. sporządzono też nowe tłoki dla powiatowych sądów ziemskich (heraldyka pieczęci nie została zmieniona, pod herbem państwowym pozostał herb pisarza; czas sporządzenia nowego tłoku wskazuje data na nim). Np. na wypisie z sądu ziemskiego w Wilnie z 1775 r. jest pieczęć, której tłok został sporządzony w 1765 r. (B. Uniwersytetu Wileńskiego, RS, f. 5-f. 118-31302/6); na wypisie z sądu ziemskiego w Trokach z 1766 r. pieczęć, której tłok został sporządzony w 1765 r. (LPAH, f. 20, ap. 1, b. 88); na wypisie z sądu ziemskiego w Kownie z 1770 r. pieczęć, której tłok został sporządzony w 1765 r. (LPAH, f. 716, ap. 2, b. 116). Również w innych powiatach po reformie 1764 r. sporządzono nowe tłoki. Zmiany zaszły również na Żmudzi: E. Rimša, G. Zabiela, Žemaitijos Kunigaikštystès Raseinių reparticijos žemés teismo spaudas, „Anykščiai: krašto kultūros ir istorijos puslapiai” 1996, nr 10, s. 2-4.

${ }^{49}$ R. Šmigelskytè-Stukienè, op. cit., s. 81-85.

${ }^{50}$ Wzory pieczęci: wypis z sądu ziemiańskiego w Lidzie z 1794 r., tłok sporządzono w $1792 \mathrm{r}$. (B. Uniwersytetu Wileńskiego, RS, f. 5-f. 122-31353/86, k. 1); wypis z sądu ziemiańskiego w Trokach z 1792 r., tłok sporządzono w 1792 r. (B. Wróblewskich, RS, f. 138-1279, k. 53).

${ }^{51}$ Wszystkie znalezione $\mathrm{w}$ trakcie badań i używane w sądach ziemskich pieczęcie są odciskane. W praktyce sądów ziemskich pieczęcie przywieszane są rzadkie; tylko jedną taką pieczęć podaje A. Szałanda; А. Шаланда, Земскія печаткі..., s. 287.

${ }^{52}$ Należy wziąć pod uwagę, że zmieniał się kształt pieczęci sądów ziemskich, np. pieczęć sądu ziemskiego w Wilnie z 1568 r. miała 29 mm (B. Uniwersytetu Wileńskiego, RS, f. 69-112), w końcu XVII w. (1690 r.) pieczęć sądu ziemskiego w Wilnie miała już 39 x 35 mm (B. Wróblewskich, RS, f. 43-680), z drugiej połowy XVIII w. (1765 r.) znamy pieczęć sądu ziemskiego w Wilnie o rozmiarach 54 x $50 \mathrm{~mm}$ (B. Uniwersytetu Wileńskiego, RS, f. 5-A28-4955) i później jeszcze bardziej się ona powiększała. Podobnie rosły rozmiary sądów ziemskich innych powiatów. Według kształtu i wielkości pieczęcie sądów ziemskich najbliższe były pieczęciom większości miast Wielkiego Księstwa. Wyjątek stanowiły pieczęcie Wilna i innych większych miast, które czasem konkurować mogły nawet z pieczęciami władców; E. Rimša, Pieczęcie miast Wielkiego Księstwa Litewskiego..., s. 111. 
Najciekawsze obserwacje można poczynić w heraldyce pieczęci sądów ziemskich. Na podstawie analizy źródeł archiwalnych pieczęcie sądów ziemskich dzielimy według heraldyki wyobrażenia napieczętnego na dwie grupy: 1) od drugiej połowy XVI do drugiej połowy XVIII w. w tarczy herbowej przedstawiano tylko godło państwa ${ }^{53}$ (co nakazywał II i III Statut) ${ }^{54}$; 2) od drugiej połowy XVII do drugiej połowy XVIII w. obok przedstawienia w górnej części pieczęci pola pieczętnego występował herb państwa, a pod nim umieszczano herb pisarza danego powiatu ${ }^{55}$. Podnosiło to znaczenie pisarza jako osoby dzierżącej konkretny tłok.

Porównując pieczęcie sądów ziemskich $\mathrm{z}$ różnych powiatów $\mathrm{z}$ drugiej połowy XVI w., można dojść do wniosku, że heraldyka pieczęci sądów ziemskich jest bardzo bliska heraldyce małych pieczęci władcy. Świadczy to, że pierwotnie tłoki pieczętne sądów ziemskich zostały sporządzone na wzór małych pieczęci władców litewskich ${ }^{56}$. Później sądy ziemskie zamawiały tłoki samodzielnie, w zależności od tego, jak długo służył tłok poprzedni (starcie się tłoku, wojny, pożary etc.).

Analiza herbu państwowego jest sprawą złożoną. Figury herbowe na pieczęciach sądów ziemskich w okresie od drugiej połowy XVI do końca XVIII w. nie były jednoznacznie ustalone. Nie wgłębiając się zbytnio w tę kwestię, odnotujmy tylko, że od XVII w. pieczęcie sądów ziemskich różnych powiatów różniły się między sobą takimi szczegółami jak broń w ręku jeźdźca, jego ubiór, kształt tarczy na lewym ramieniu i figura herbowa na niej, wodze, uzdy etc. ${ }^{57}$

${ }^{53}$ Zob. wyżej, przyp. 30.

${ }^{54} \mathrm{~Np}$. herb państwa bez herbu pisarza na pieczęci na wypisie z sądu ziemskiego w Grodnie z 1774 r. (LPAH, f. 716, ap. 4, b. 98, k. 54); zob. też wyżej, przyp. 31.

${ }^{55} \mathrm{Na}$ pytanie, dlaczego sądy ziemskie nie we wszystkich powiatach używały tylko herbu państwowego, nie znamy odpowiedzi. Kwestia: w którym sądzie ziemskim jako pierwszym wprowadzono na pieczęć herb pisarza nie została jeszcze zbadana. Godło pisarza stanowił tylko jeden jego herb rodowy. Umieszczany był najczęściej w tarczy, po bokach zaś herbu pisarza widniały po trzy wielkie litery oznaczające: imię, nazwisko, funkcję i powiat, w którym się znajdował sąd ziemski. Np. na pieczęci sądu ziemskiego w Wilnie u góry znajduje się herb państwa, u dołu zaś herb pisarza, a po bokach herbu pisarza litery - FPW i ZZW. W rozwinięciu brzmi to: Felicjan Zmijowski, pisarz ziemski województwa wileńskiego. Na wypisie z sądu ziemskiego w Wilnie z 1775 r. pieczęć, której tłok został sporządzony w 1765 r. (B. Uniwersytetu Wileńskiego, RS, f. 5-f. 118-31302/6). Rzadsze są przypadki, kiedy z góry umieszczony jest herb państwa, w dole zaś tylko figura herbowa pisarza bez tarczy, a wokół herbu litery wskazujące na jego imię, nazwisko i funkcje; np. pieczęć na wypisie z sądu kapturowego w Grodnie z 1669 r. (LPAH, f. 1029, ap. 1, b. 63, k. 5). Podobnie rzadkie są przypadki, kiedy pod herbem państwowym umieszczony jest herb pisarza na tarczy, ale bez jego inicjałów dokoła, np. na pieczęci na wypisie z sądu ziemskiego w Brasławiu z 1780 r. (B. Uniwersytetu Wileńskiego, RS, f. 67-3092). Rzadkie są przypadki, kiedy herb pisarza zasłania nawet o kilka milimetrów herb państwowy. Tak samo rzadkie są przypadki, kiedy mamy po cztery litery po bokach, np. na pieczęci na wypisie z sądu ziemskiego w Kownie z 1771 r. (B. Wróblewskich, RS, f. 43-9912).-

${ }^{56}$ Np. mała pieczęć litewska Zygmunta Augusta; Sigilla regum et reginarum Poloniae. Pieczęcie królów i królowych Polski ze zbiorów Archiwum Głównego Akt Dawnych, Warszawa 2015, s. 51.

${ }^{57}$ Różne też były sposoby wyobrażania jeźdźca i konia na pieczęciach sądów ziemskich w XVI-XVIII w. Można tu wymienić kilka, np. od lat 60. XVI w. jeździec trzyma uniesiony miecz, a od 
Wiele nie mniej istotnych szczegółów ukazuje też analiza heraldyki sądów ziemskich. Kształt tarcz używanych w wyobrażeniach herbów na pieczęciach sądów ziemskich zmieniał się z upływem czasu, nierzadko stosowano też tarczę z wcześniejszych okresów. Na pieczęciach sądów ziemskich rzadko umieszczana była tarcza pod herbem państwa, a powyżej herbu pisarza ${ }^{58}$. Równie rzadko spotykamy tam też trzymacz ${ }^{59}$. Płaszcze na pieczęciach sądów ziemskich bardziej popularne stały się dopiero $\mathrm{w}$ drugiej połowie XVIII w. ${ }^{60} \mathrm{Na}$ tychże pieczęciach nad herbem państwa umieszczano korony rangowe, ale w XVII-XVIII w. najczęściej mitrę książęcą ${ }^{61}$. Jeżeli na pieczęci sądu ziemskiego użyty był też herb pisarza, umieszczano nad nim 5-9-listny wieniec ${ }^{62}$. Od drugiej połowy XVII w. używano również innych elementów zdobniczych, np. różnych motywów roślinnych czy panopliów ${ }^{63}$.

Legendy pisane były pismem majuskulnym w otoku pieczęci, poczynając od góry, zgodnie z ruchem wskazówek zegara. Legenda zajmowała najczęściej jeden wiersz wzdłuż okręgu ${ }^{64}$. Jak już wspomniano, II i III Statuty litewskie ustanawiały, że w legendzie pieczęci sądu ziemskiego wokół herbu ma być zapisana nazwa powiatu. Szczegółowe badanie legend wykazało, że norma ta była przestrzegana ${ }^{65}$.

drugiej połowy XVII w. znajdujemy już szablę. Od lat 60. XVI w. koń ma ogon podniesiony, od pierwszej połowy XVII w. opuszczony i taki pozostaje do końca kolejnego stulecia itd. Tylko szczegółowe badania pozwolą dokładniej określić, kiedy i w jakich powiatowych sądach ziemskich ta czy inna nowość pojawiła się na pieczęci; okazać się też może, że zmiany heraldyczne przejmowało jednocześnie nawet kilka powiatów.

${ }^{58}$ Wypis z sądu ziemskiego w Wilnie z 1791 r. z pieczęcią wileńskiego sądu ziemskiego (data 1783 w legendzie pieczęci oznacza najpewniej rok sporządzenia tłoku); B. Uniwersytetu Wileńskiego, RS, f. 5-f. 90-26637.

${ }^{59} \mathrm{Na}$ pieczęci sądu ziemskiego w Wiłkomierzu z 1766 r. przedstawiony jest jeden trzymacz pod herbem państwowym obok herbu pisarza; LPAH, f. 79, ap. 1, b. 206, k. 127.

${ }^{60} \mathrm{Na}$ pieczęci na wypisie z sądu ziemskiego w Trokach z 1777 r. przedstawiony jest płaszcz; B. Wróblewskich, RS, f. 264-618.

${ }^{61} \mathrm{Na}$ wypisie z sądu ziemskiego w Wilnie z 1775 r. z pieczęcią sądu ziemskiego w Wilnie; B. Uniwersytetu Wileńskiego, RS, f. 5-B2-326.

${ }^{62} \mathrm{~Np}$. wieniec pięciolistny na wypisie z sądu ziemskiego w Kownie z 1770 r.; LPAH, f. 716, ap. 2, b. 116, k. 205.

${ }^{63}$ Np. panoplia na pieczęci na wypisie z sądu ziemskiego w Wilnie z 1698 r.; B. Wróblewskich, RS, f. 318-25021.

${ }^{64}$ Udało się stwierdzić tylko pojedyncze przypadki, kiedy ze wzrostem ilości informacji legenda została przeniesiona do drugiego wiersza. Na pieczęci sądu ziemskiego w Oszmianie z $1789 \mathrm{r}$. znajdujemy legendę w dwóch wierszach; B. Wróblewskich, RS, f. 43-5559.

${ }^{65}$ W legendach najstarszych pieczęci sądów ziemskich (1564-1566) znajdujemy: „Pieczęć powiatu [...] Wielkiego Księstwa Litewskiego" (różne są tylko nazwy powiatu). Np. wypis z Trybunału Głównego Litewskiego z 1599 r. z pieczęcią sądu ziemskiego w Wilnie, jego legenda głosi: „PIECECZ • POVIATV • WILENSKIEGO VL KZ LI”; B. Uniwersytetu Wileńskiego, RS, f. 13-60, k. 11v. Od drugiej połowy XVI w. widać, do którego sądu ziemskiego należy pieczęć: „Pieczęć ziemska powiatu ...” (różnią się tylko nazwy powiatu), np. wypis z sądu ziemskiego w Kownie z 1770 r. z pieczęcią sądu ziemskiego w Kownie - w jej legendzie czytamy: „PIECZENC 
Legendy na pieczęciach sądów ziemskich pisano po polsku. Sporadycznie znajdujemy tylko pojedyncze słowa łacińskie. Skróty w legendach występowały rzadko ${ }^{66}$. Zwykle na omawianych pieczęciach używano cyfr arabskich. Od końca XVI do drugiej połowy XVII w. daty pisano przeważnie w polu pieczęci pod herbem państwa, od drugiej zaś połowy XVII w. na końcu legendy w otoku. Na pieczęciach sądów ziemskich data oznaczać mogła po prostu czas sporządzenia tłoku.

Zmieniał się też kształt opisywanych pieczęci. W Wielkim Księstwie Litewskim znane i stosowane były dwa kształty pieczęci sądów ziemskich: okrągły i owalny. Najwcześniejsze pieczęcie sądów ziemskich były okrągłe. Kształt ten był popularny do drugiej połowy XVIII w., natomiast od początku drugiej połowy XVII w., kiedy pod godłem państwa zaczęto umieszczać herb pisarza, w wielu powiatach pojawiły się pieczęcie owalne. Jednak modny wówczas kształt owalny nie wyeliminował pieczęci okrągłych. Obie formy funkcjonowały równolegle.

Do pieczętowania pozwów sądy ziemskie używały materiału pieczętnego (wosku, woszczku) w zaszczytniejszym kolorze czerwonym ${ }^{67}$ - z pewnością dlatego, że wystawiano je przed imieniem władcy. Odnalezione źródła świadczą, że formy pieczętowania w sądach ziemskich były różne i zmieniały się z upływem czasu ${ }^{68}$.

Gdy powstał Trybunał Główny Litewski, zgodnie z jego statutem pieczęcie sądów ziemskich odciskano również na jego dokumentach. Odnajdujemy je tam od 1581 r. do począatku XVIII w. ${ }^{69}$ Tłoków sądów ziemskich używały także działające w okresach bezkrólewia sądy kapturowe ${ }^{70}$.

•ZIEMSKA • POWIATU • KOWIENSKIEGO • ROKU 1765...”; LPAH, f. 716, ap. 2, b. 116, k. 205. Wśród legend pieczęci sądów ziemskich są wyjątki: np. na pieczęci sądu ziemskiego właściwego dla stołecznego powiatu województwa używano, jak w Wilnie i Trokach, nazwy województwa.

${ }^{66} \mathrm{~Np}$. zapis nazwy Wielkiego Księstwa Litewskiego był skrócony: pieczęć sądu ziemskiego w Wilnie na wypisie z Trybunału Głównego Litewskiego z 1588 r. (B. Wróblewskich, RS, f. 16-75, k. 87v); znajdujemy też skrót słowa „rok” do dwóch liter RO: wypis z Trybunału Głównego Litewskiego z 1727 r. z pieczęcią sądu ziemskiego w Wilnie (LPAH, f. 20, ap. 1, b. 69, k. 25).

${ }^{67}$ Bez dokładnych badań nie sposób ustalić, czy jest to wosk, czy woszczek, dlatego używam terminu „materiał pieczętny”. Pozew z 1597 r. z pieczęcią sądu ziemskiego w Brasławiu (B. Wróblewskich, RS, f. 16-84, k. 19); pozew z 1568 r. z pieczęcią sądu ziemskiego w Kownie (B. Wróblewskich, RS, f. $38-1$, k. 60 v).

${ }^{68}$ Osobnym obiektem dociekań i tematem czekającym jeszcze na swych badaczy jest szczegółowe zbadanie formuł pieczętowania.

${ }^{69}$ Regulacja norm używania tłoków sądów ziemskich w Trybunale Głównym Litewskim zob.: A. Janulaitis, Vyriausiasis Lietuvos tribunolas XVI-XVIII amž. Jo atsiradimas, veikimas ir reikšmé Lietuvos gyvenime, Kaunas 1927, s. 140-141, 144 (art. 13 i 16 statutu Trybunału Głównego Litewskiego). Normy te zostały wdrożone do praktyki. Niewątpliwie w Wilnie pieczętowano tłokiem wileńskiego sądu ziemskiego, w Mińsku - mińskiego, w Nowogródku - nowogródzkiego, np. wypis z Trybunału Głównego Litewskiego w Wilnie z 1599 r. ma pieczęć sądu ziemskiego w Wilnie (B. Wróblewskich, RS, f. 43-3900, 1. 22); wypis z Trybunału Głównego Litewskiego w Nowogródku z 1723 r. opatrzony jest pieczęcią sądu ziemskiego w Nowogródku (B. Wróblewskich, RS, f. 264-140, k. 23). Od początku XVIII w. znajdujemy już osobne pieczęcie Trybunału Głównego Litewskiego, np. w 1752 r. pieczęć Trybunału Głównego Litewskiego w Mińsku (LPAH, 


\section{Pieczęcie urzędników sądów ziemskich}

Jak już wspomniano, pieczęcie urzędników sądów ziemskich znajdujemy na wszystkich dokumentach tych sądów, z wyjątkiem pozwów, te bowiem opatrywane były pieczęcią sądu ziemskiego.

Pieczęcie urzędników sądów ziemskich - sędziego i podsędka - były odciskane $^{71}$. Od lat 60 . XVI w. do reformy $1764 \mathrm{r}$. wykazywały one, jeśli chodzi o rozmiary, tendencję wzrostową ${ }^{72}$. W Wielkim Księstwie Litewskim znano i używano trzech kształtów pieczęci urzędników sądu ziemskiego: okrągłych, owalnych i ośmiobocznych ${ }^{73}$.

Na podstawie analizy źródeł archiwalnych pieczęcie herbowe urzędników sądu ziemskiego - sędziów i podsędków - dzielimy według heraldyki wyobrażenia napieczętnego na dwie grupy: wyobrażenie jednego herbu lub kilku albo też herb złożony w podzielonej tarczy herbowej.

Heraldyka pieczęci urzędników sądu ziemskiego nie była w jakikolwiek sposób normowana. Na ich pieczęciach herbu państwowego nie umieszczano. Urzędnicy sądu ziemskiego mogli wybierać, czy zamieszczać jeden herb z jednym godłem lub też herb złożony. Zwykle $\mathrm{w}$ jednym polu przedstawiony był jednolity herb rodowy. W herbach złożonych natomiast najbardziej rozpowszechnione były tarcze czteropolowe. Od drugiej połowy XVI w. na pieczęciach występowały jednak nawet bardziej złożone herby - o tarczach pięciopolowych, z herbami ojca, matki, dziadków, a czasami nawet pradziadków ${ }^{74}$. Podkreślały one nie tylko

f. 20, ap. 1, b. 84); wypis z 1751 r. z Trybunału Głównego Litewskiego w Mińsku (B. Wróblewskich, RS, f. 86-53, k. 104); wypis z 1745 r. z Trybunału Głównego Litewskiego w Wilnie (B. Wróblewskich, RS, f. 198-393, k. 8); wypis z 1713 r. z Trybunału Głównego Litewskiego w Wilnie (LPAH, f. 1292, ap. 1, b. 44, k. 43). Pieczęcie Trybunału Głównego Litewskiego były publikowane; zob. Deputaci Trybunału Głównego Wielkiego Księstwa Litewskiego (1697-1794). Spis, red. A. Rachuba, Warszawa 2004, s. 403-404. Heraldyka Trybunału Głównego Litewskiego bliska jest pieczęciom sądów ziemskich WKL: u góry przedstawienia pieczętnego umieszczony jest herb państwa, u dołu - herb pisarza. Różne są tylko legendy.

${ }^{70}$ Obecnie znanych jest kilka przykładów z lat 60. XVII w.: wypis z sądu kapturowego z $1669 \mathrm{r}$. z pieczęcią sądu ziemskiego w Grodnie (LPAH, f. 1029, ap. 1, b. 63, k. 5). W latach 30. XVIII w. niewątpliwie istnieją już też osobne pieczęcie sądu kapturowego, np. pieczęć sądu kapturowego powiatu wiłkomierskiego z 1733 r.; E. Rimša, Heraldry. Past to Present..., s. 106.

${ }^{71}$ Wszystkie wykorzystane do badań pieczęcie są odciskane. Pieczęci przywieszanych nie znaleziono.

${ }^{72}$ Pieczęć sędziego była najczęściej większa od pieczęci podsędka. Zdarzają się jednak i takie przypadki, kiedy pieczęć podsędka była większa lub równa rozmiarem z pieczęcią sędziego.

${ }^{73}$ Kształt pieczęci sędziego i podsędka niekoniecznie był uzgadniany: pieczęć sędziego mogła być okrągła, a podsędka - ośmioboczna etc.

${ }^{74}$ Przykłady herbów łączonych z pięciopolowymi tarczami: pieczęć sędziego J. Ościka na dokumencie sądu ziemskiego w Wilnie z 1599 r. (B. Uniwersytetu Wileńskiego, RS, f. 13-60, k. 15); pieczęć podsędka A. Wołłowicza na wypisie z sądu ziemskiego w Wiłkomierzu z 1591 r. (B. Wróblewskich, RS, f. 12-4326, k. 4). 
szlachetność urodzenia właściciela tłoku, ale i jego koneksje rodowe o walorach genealogicznych.

Najciekawsze spostrzeżenia przynosi analiza heraldyki pieczęci urzędników sądu ziemskiego - sędziów i podsędków. Kształt tarcz używanych na pieczęciach herbowych urzędników sądów ziemskich zmieniał się z czasem, nierzadko jednak korzystano również z formy tarcz wcześniejszego okresu. Urzędnicy sądów ziemskich wykazywali szczególne upodobanie do eksponowania hełmu herbowego, a najbardziej popularny był zwrócony ku patrzącemu hełm prętowy ${ }^{75}$. Na pieczęciach urzędników przedstawiano też najważniejszą część zwieńczenia herbu, czyli klejnot, często z godłem tautologicznym ${ }^{76}$. Zgromadzony materiał źródłowy ukazuje, że najczęściej przedstawiano w klejnocie 3-5 piór, zwierzęta natomiast ukazywano do połowy. Oczywiście klejnoty mogły być niezwiązane z figurą herbową, jednak w przypadku klejnotu tautologicznego mogło powtarzać pod względem kształtu i wyglądu całość lub część przedstawionej na tarczy figury herbowej ${ }^{77}$. Od końca XVI do końca XVIII w. na pieczęciach urzędników sądów ziemskich znajdujemy najczęściej labry roślinne ${ }^{78}$. Używano także koron rangowych - znajdujemy koronę hełmową, zwieńczoną pięcioma pałkami, a najczęściej pięcioliściem ${ }^{79}$. Czasem wykorzystywano też inne elementy zdobnicze, np. różne motywy roślinne lub panoplia ${ }^{80}$.

Na podstawie zanalizowanych dotychczas pieczęci urzędników sądów ziemskich napisy na ich wyobrażeniach podzielić możemy na dwie grupy: 1) prywatne - gdy nad herbem umieszczano są dwie, rzadziej trzy wielkie litery łacińskie inicjały imienia i nazwiska (bądź imienia, drugiego imienia lub patronimicum

${ }^{75}$ Zwrócony ku patrzącemu hełm prętowy: pieczęć podsędka A.S. Bielikowicza na wypisie z sądu ziemskiego w Oszmianie z 1586 r. (B. Wróblewskich, RS, f. 16-17, k. 150); na pieczęciach sędziego J. Radoszyńskiego i podsędka G. Beynarta na wypisie z sądu ziemskiego w Kownie z 1584 r. (LPAH, f. 1177, ap. 1, b. 214, k. 3v).

${ }^{76}$ U góry tarczy hełm, nad nim godło tautologiczne.

${ }^{77} \mathrm{~Np}$. trzy pióra na pieczęci sędziego sądu ziemskiego w Upicie J. Zygmuntowicza na wypisie z 1599 r. (B. Uniwersytetu Wileńskiego, RS, f. 8-1678). Rzadziej godło tautologiczne pod względem kształtu czy wyglądu powtarzało całą lub część figury herbowej na tarczy; np. herb Bończa na pieczęci podsędka sądu ziemskiego w Kownie W. Kulwińskiego na wypisie z 1596 r. (LPAH, f. 716, ap. 2, b. 137, k. $101 \mathrm{v}$ ); zwierzęta przedstawiano zwykle do połowy, np. na pieczęci sędziego sądu ziemskiego w Trokach B.F. Sapiehy na wypisie z 1582 r. (B. Wróblewskich, RS, f. 16-75, k. 104).

${ }^{78} \mathrm{~Np}$. labry roślinne na pieczęci sędziego sądu ziemskiego w Kownie J. Radoszyńskiego na wypisie z 1581 r.; LPAH, f. 1195, ap. 1, b. 12, k. 13.

${ }^{79} \mathrm{~Np}$. koronka hełmowa na pieczęci podsędka sądu ziemskiego w Oszmianie S.A. Świrskiego na wypisie z 1607 r. (LPAH, f. 1177, ap. 1, b. 2695, k. 37).

${ }^{80}$ Gałązki roślinne znajdujemy na pieczęci sędziego sądu ziemskiego w Oszmianie K. Kamińskiego na wypisie z 1715 r. (B. Uniwersytetu Wileńskiego, RS, f. 4-(A-655)-25127); panoplia pojawiają się na pieczęci podsędka sądu ziemskiego w Lidzie na wypisie z 1754 r. (B. Uniwersytetu Wileńskiego, RS, f. 5-f. 122-31353/62). Zagadnienie koron rangowych i godeł tautologicznych wymaga jeszcze dalszych badań, ponieważ pieczęcie urzędników sądów ziemskich zachowały się w bardzo złym stanie, wskutek czego trudno jest prześledzić ich rozwój. 
i nazwiska) ${ }^{81}$ oraz 2) urzędnicze, dzielące się na trzy podgrupy. Pierwsza z nich zawiera tylko inicjały osobiste urzędnika, wówczas nad herbem widzimy dwie, rzadziej trzy wielkie litery łacińskie, oznaczające imię i nazwisko posiadacza tłoku, a po bokach herbu pojawiają się dodatkowo dwie wielkie litery łacińskie na oznaczenie powiatu, którego był on urzędnikiem (w przypadku trzech liter było to imię, drugie imię lub patronimicum i nazwisko) ${ }^{82}$. Drugi typ zawiera tylko legendę. Były one pisane literami alfabetu łacińskiego w typie majuskulnym, wzdłuż krawędzi tłoku, zgodnie z ruchem wskazówek zegara. Legenda zajmowała jeden wiersz na obwodzie. Legendy na pieczęciach urzędników sądów ziemskich pisane były po polsku. Słowa łacińskie pojawiają się bardzo rzadko. W legendzie wskazywano imię, nazwisko i funkcje urzędnika. Czasem podawano też nazwę powiatu ${ }^{83}$. Ostatni typ zawierał zarówno legendę, jak i inicjały urzędnika ${ }^{84}$.

Daty na wyobrażeniach pieczęci urzędników podawano stosunkowo rzadko. Pisano je w polu pieczęci: ponad lub pod tarczą bądź po jej bokach lub w otoku legendy. Daty na pieczęciach oznaczały albo początek pełnienia przez urzędnika obowiązków służbowych, albo też czas sporządzenia sygnetu bądź tłoku. Używany przez urzędników sądów ziemskich materiał pieczętny (wosk, woszczek) był koloru czerwonego, czarnego, zielonego i brązowego ${ }^{85}$. W koroboracjach dokumentów wydanych przez urzędników sądów ziemskich najczęściej spotykane są następujące formuły pieczętowania: „Z naszymi pieczęciami” ${ }^{\circ 6}$, „Z naszymi pieczęciami urzędowymi”87 lub ,z naszymi pieczęciami sędziowskimi”"88. Nierzadko w koroboracjach odnotowywano, że dokument został opatrzony nie tylko

${ }^{81}$ Na pieczęci podsędka sądu ziemskiego w Lidzie Stanisława Tukałły na wypisie z 1617 r. nad herbem litery S i T; B. Wróblewskich, RS, f. 21-1283, k. 26v.

${ }^{82} \mathrm{Na}$ pieczęci podsędka sądu ziemskiego w Kownie J. Gimbutta na wypisie z 1638 r. nad herbem litery I i G, po bokach herbu - P i K (Jan Gimbutt, podsędek kowieński); B. Wróblewskich, RS, f. 43-18042.

${ }^{83} \mathrm{~W}$ legendzie pieczęci podsędka sądu ziemskiego w Wiłkomierzu J. Białłozora na wypisie z $1731 \mathrm{r}$.: * IAKVB • BIALLOZOR • PODSEDEK • WILKOMIERSKI •; B. Uniwersytetu Wileńskiego, RS, f. 5-A28, 4975.

${ }^{84} \mathrm{Na}$ pieczęci podsędka sądu ziemskiego w Oszmianie S.M. Naramowskiego na wypisie z 1715 r.; B. Uniwersytetu Wileńskiego, RS, f. 4-(A658)-25127. Legenda pieczęci i inicjały zachowały się w bardzo złym stanie.

${ }^{85}$ Jak już wspomniano, bez dodatkowych badań nie da się zidentyfikować rodzaju tworzywa, dlatego używam terminu „materiał pieczętny” - czerwonego użył sędzia sądu ziemskiego w Trokach B.F. Sapieha na wypisie z 1582 r. (B. Wróblewskich, RS, f. 16-75, l. 104), zielonego - sędzia sądu ziemskiego w Brasławiu G.G. Mirski i podsędek tegoż sądu W.I. Massalski na wypisie z 1600 r. (B. Wróblewskich, RS, f. 43-16663).

${ }^{86}$ Oryg. Под нашыми печатми na wypisie z ksiąg sądu ziemskiego w Wilnie z 1598 r.; B. Uniwersytetu Wileńskiego, RS, f. 13-60, k. 5 a.

${ }^{87}$ Oryg. Под нашыми врадовыми печатми na wypisie z ksiąg sądu ziemskiego w Wilnie z 1614 r.; B. Wróblewskich, RS, f. 264-458.

${ }^{88}$ Oryg. Под нашыми судеискими печатми na wypisie z ksiąg sądu ziemskiego w Brasławiu z 1598 r.; B. Wróblewskich, RS, f. 16-85, k. 203. 
pieczęciami, ale i podpisem pisarza ${ }^{89}$. Jak już wspomniano, pisarz sądu ziemskiego musiał podpisywać wszystkie dokumenty. Normy tej bezwzględnie przestrzegano: podpis pisarza figuruje niezmiennie obok pieczęci sędziego i podsędka od lat 60 . XVI w. do reformy przeprowadzonej w $1764 \mathrm{r} .{ }^{90}$ Podpisując się, pisarz podawał swoje imię, nazwisko i powiat ${ }^{91}$. Ów podpis uwierzytelniał treść i legalność spisanego dokumentu, pełnił też funkcję prewencyjną, zapobiegając możliwościom sporządzenia falsyfikatów.

Podsumowując, można stwierdzić, że nieobecna dotąd w historiografii wiedza o pieczęciach pozwala na sformułowanie nowych i ważnych wniosków w tej kwestii. Znalezione $w$ archiwach materiały źródłowe potwierdzają jednoznacznie, że zawarte w II i III Statucie litewskim oraz wprowadzone w ramach reformy w 1764 r. normy określające używanie pieczęci sądów ziemskich i ich urzędników były przestrzegane. Choć nie ulega wątpliwości, że naszą wiedzę z pewnością uzupełni odnalezienie niebadanego dotychczas materiału źródłowego. Jednak już omawiany $\mathrm{w}$ artykule materiał daje możliwości do bardziej gruntownych podsumowań dotyczących tematu pieczęci sądów ziemskich i ich urzędników w Wielkim Księstwie Litewskim.

\section{Streszczenie}

Sądy ziemskie, powołane po reformach administracyjnych przeprowadzonych w Wielkim Księstwie Litewskim w latach 1564-1566, zajmowały się głównie sprawami cywilnymi i pełniły funkcję notariatu. Od momentu powstania każdy sąd ziemski posługiwał się własnymi tłokami: tłokiem sądu, przystawianym wyłącznie do pozwów, oraz tłokami swoich urzędników: sędziego i podsędka, używanych dla wszystkich innych dokumentów podpisywanych przez pisarza sądowego. Źródła archiwalne potwierdzają, że wprowadzone przez statuty litewskie oraz konstytucje sejmowe prawne regulacje użycia pieczęci sądów ziemskich i ich urzędników były przestrzegane w praktyce. Artykuł prezentuje wnioski płynące $\mathrm{z}$ wnikliwej analizy heraldycznej i sfragistycznej około dwustu niepublikowanych wcześniej pieczęci sądów ziemskich i ich urzędników z dziewięciu powiatów województw wileńskiego i trockiego Wielkiego Księstwa Litewskiego, przechowywanych w zbiorach bibliotecznych i archiwalnych. Praktyki używania odrębnych tłoków przez urzędników sądowych, sędziego i podsędka zaniechano po reformie administracyjnej z 1764 r., wprowadzającej jeden tłok dla każdego sądu ziemskiego. Reformy Sejmu Czteroletniego wprowadziły jednolity podział administracyjny i zreorganizowały dotychczasowy system sądowy, zastępując sądy ziemskie, grodzkie i podkomorskie nowymi instytucjami. Można znaleźć wiele podobieństw do innych rejonów Wielkiego Księstwa Litewskiego, ale jest to temat na odrębną rozprawę.

\footnotetext{
${ }^{89}$ Na wypisie z ksiąg sądu ziemskiego w Oszmianie z 1597 r.; B. Wróblewskich, RS, f. 16-84, k. 95.

${ }^{90}$ Po reformie 1764 r. pisarz sądu ziemskiego podpisywał wszystkie rodzaje dokumentów sądowych.

${ }^{91}$ Wypis z ksiąg sądu ziemskiego w Lidzie z 1591 r. podpisał Wojciech Skinder, pisarz sądu ziemskiego w Lidzie; B. Wróblewskich, RS, f. 16-79, k. 175v.
} 


\section{Seals of Land Courts in the Grand Duchy of Lithuania in 1564-1792 Summary}

Established after the reform of 1564-1566, land courts handled civil cases and performed notarial functions. From their establishment, each district land court had its own institutional stamps: the stamp of the land court used exclusively for summons (issued in the name of the sovereign), and stamps of the land court officials (the judge and the sub-judge) used for all other land court documents signed by the land court Scribe. Archival sources confirm that the regulations established in the articles of the Lithuanian Statutes and Sejm Constitutions concerning the use of seals of the land court and its officials were implemented in real-life practice. A thorough heraldic and sphragistic analysis of seals of the land court and its officials in the Wilno (Vilnius) and Troki (Trakai) palatinates (nine districts) of the Grand Duchy of Lithuania is presented, based on about two hundreds of previously unpublished seals, kept in library and archive collections. The practice of using different stamps of land court officials, the judge and sub-judge, was discontinued after the 1764 reform, and a single land court stamp was used by each district land court after that time. In 1788-1792, the Four-Year Sejm introduced a new administrative division and reorganized the existing court system, namely, it replaced district courts, the castle court, the land court, and the underchamber court with new institutions. Similarities can be found in other districts of the Grand Duchy of Lithuania, but this should be an object of further detailed research.

\section{Bibliografia}

\section{Źródła drukowane}

Lappo J., 1588 m. Lietuvos Statutas, t. 2: Tekstas, Kaunas 1938.

Pirmasis Lietuvos Statutas, t. 2, cz. 1: Tekstai senaja baltarusiu, lotynu ir senaja lenkų kalbomis, wyd. S. Lazutka et al., Vilnius 1991.

Statut Litewski drugiej redakcyi (1566), w: Pomniki prawa litewskiego z XVI wieku, wyd. F. Piekosiński, Kraków 1900 (Archiwum Komisyi Prawniczej, t. 7).

Valikonytė I., Lazutka S., Gudavičius E., Pirmasis Lietuvos Statutas (1529 m.), Vilnius 2001.

Volumina legum, t. 7: Ab anno 1764 ad annum 1768, wyd. J. Ohryzko, Petersburg 1860.

Акты, издаваемые Виленскою комиссиею для разбора древних актов, t. 22: Акты Слонимского земского суда, Вильна 1895.

Статут Вялікага княства Літоўскага 1566 года, wyd. Т.І. Даўнар et al., Мінск 2003.

\section{Opracowania}

Adamczewski M., Pieczęcie urzędowe władz lokalnych z obszaru Polski centralnej, Łódź 2010.

Baliński M., Historya miasta Wilna, t. 2, Wilno 1836.

Bardach J., Statuty litewskie a prawo rzymskie, Warszawa 1999.

Deputaci Trybunału Głównego Wielkiego Księstwa Litewskiego (1697-1794). Spis, red. A. Rachuba, Warszawa 2004.

Diederich T., Siegelkunde, Beiträge zu ihrer Vertiefung und Weiterführung, Böhlau-Wien 2012.

Ewald W., Siegelkunde, München-Berlin 1914.

Galkus J., Lietuvos Vytis, Vilnius 2009.

Gumowski M., Handbuch der polnischen Siegelkunde, Graz 1966.

Gumowski M., Haisig M., Mikucki S., Sfragistyka, Warszawa 1960. 
Hedemann O., Historja powiatu brasławskiego, Wilno 1930.

Ilgen Th., Sphragistik, w: Grundriß der Geschichtswissenschaft, t. 1, cz. 4, red. A. Meister, Leipzig-Berlin 1912, s. 1-58.

Jankowski C., Powiat oszmiański. Materjały do dziejów ziemi i ludzi, cz. 1, Petersburg 1896.

Janulaitis A., Vyriausiasis Lietuvos tribunolas XVI-XVIII amž. Jo atsiradimas, veikimas ir reikšmé Lietuvos gyvenime, Kaunas 1927.

Jodkowski J., Pieczęcie polskie w muzeum Rumiancowskiem w Moskwie, „Wiadomości Numizmatyczno-Archeologiczne" 2, 1910, nr 6, s. 94-96.

Kittel E., Siegel, Braunschweig 1970.

Piech Z., Monety, pieczęcie i herby w systemie symboli władzy Jagiellonów, Warszawa 2003.

Ragauskienė R., Dingę istorijoje. XVI a. Lietuvos Didžiosios Kunigaikštystès privatūs archyvai, Vilnius 2015.

Ragauskienė R., Galimybès klastoti bajorijos dokumentus Lietuvos Didžiojoje Kunigaikštystèje XVI a., „Istorijos šaltinių tyrimai”, 1, 2008, s. 219-249.

Rimša E., The Heraldry of Lithuania, tłum. V. Urbonavičius, D. Barnard, Vilnius 2008.

Rimša E., Heraldry. Past to Present, tłum. V. Arbas, Vilnius 2005.

Rimša E., Lietuvos didžiojo kunigaikščio Vytauto antspaudai ir žemiu heraldika, Vilnius 2016.

Rimša E., Pieczęcie miast Wielkiego Księstwa Litewskiego, tłum. J. Sienkiewicz, Warszawa 2007.

Rimša E., Zabiela G., Žemaitijos Kunigaikštystès Raseiniu reparticijos žemès teismo spaudas, „Anykščiai: krašto kultūros ir istorijos puslapiai” 1996, nr 10, s. 2-4.

Seyler G.A., Geschichte der Siegel, Leipzig 1894.

Sigilla regum et reginarum Poloniae. Pieczęcie królów i królowych Polski ze zbiorów Archiwum Głównego Akt Dawnych, Warszawa 2015.

Stieldorf A., Siegelkunde, Hannover 2004.

Šmigelskytė-Stukienè R., Lietuvos Didžiosios Kunigaikštystes pavieto teismu notarinès funkcijos, w: Lietuvos notariato istorija, red. J. Karpavičienè, Vilnius 2012, s. 71-94.

Šmigelskytė-Stukienè R., Brusokas E., Glemža L. et al., Modernios administracijos tapsmas Lietuvoje. Valstybès instituciju raida 1764-1794 metais: kolektyviné monografija, Vilnius 2014.

Urzędnicy Wielkiego Księstwa Litewskiego. Spisy, t. 1: Województwo wileńskie XIV-XVIII wiek, red. A. Rachuba, Warszawa 2004.

Urzędnicy Wielkiego Księstwa Litewskiego. Spisy, t. 2: Województwo trockie XIV-XVIII wiek, red. A. Rachuba, Warszawa 2009.

Vilimas D., Kauno žemés teismas paskutiniaisiais Stepono Batoro valdymo metais, „Lituanistica” 57, 2011, nr 3(85), s. 227-242.

Vilimas D., LDK pavieto Žemes teismu funkcija - tarp notariato ir teismo (iki $1588 \mathrm{~m}$.) (lietuvišku pavietu atvejis), „Lituanistica” 57, 2011, nr 4(86), s. 355-364.

Vilimas D., Lietuvos Didžiosios Kunigaikštystès žemès teismo sistemos formavimasis (1564-1588), Vilnius 2006.

Алфьоров О., Однороженко О., Українські особові печатки XV-XVII cm. За матеріалами київських архивосховищ, Харків 2008.

Лаппо И., Великое Княжество Литовское во второй половине XVI столетия. Литовско- русский повет и его сеймик, Юрьев 1911.

Лаппо И., Великое Княжество Литовское за время от заключения Люблинской унии до смерти Стефана Батория (1569-1586), сz. 1, С.-Петербург 1901.

Лаппо И., Земский суд в Великом Княжестве Литовском в коние XVI века, С.-Петербург 1897. Любавский М., Литовско-русский сейм, Москва 1900.

Сапунов А.П., Витебская старина, t. 1, Витебск 1883.

Семянчук Г., Агульнае и асабівае у шляхецкай геральдыцы Гарадзенскага павета другой паловы XVI-пачатку XVII cm., „Сфрагистичний щорічник” 4, 2013, s. 424-433. 
Соболева Н.А., Русские печати, Москва 1991.

Цитоу А., Геральдикыка Беларуси, Минск 2007.

Цитоу А., Пячатки старажытнай Беларуси. Нарысы сфрагистыки, Минск 1993.

Цитоу А., Сфрагистыка и Геральдикыка Беларуси, Минск 1999.

Шаланда А., Геральдыка Валовічаў XVI-XVIII стст. Мифы і рэальнасць, w: Unus pro omnibus. Валовічы ў гісторыі Вялікага княства Литоўскага XV-XVIII cmcm., орrac. А.М. Янушкевіч, red. А.І. Шаланда, Мінск 2014, s. 145-187.

Шаланда А., Земскія печаткі Вялікага Княства Літоўскаго у XVI-XVIII cm. Аснаўныя тыпы, „Сфрагистичний щорічник” 4, 2013, s. 277-298.

Justina Sipavičiūtė - doktorantka w Instytucie Historii Litwy. Przygotowuje rozprawę doktorską na temat: „Pieczęcie w państwowym systemie sądowniczym Wielkiego Księstwa Litewskiego w XVI-XVIII w." Promotor doc. dr Edmundas Rimša. E-mail: justinasipav@gmail.com 


\section{Aneks}

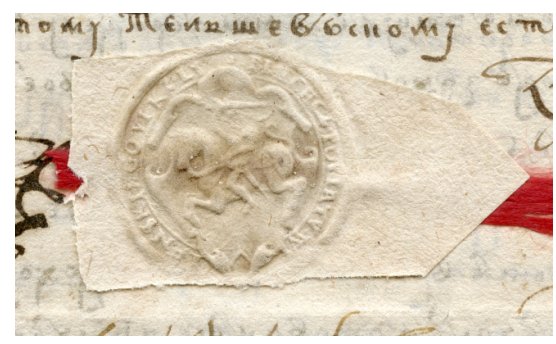

Il. 1. 1604 r., wypis z sądu Trybunału Głównego WKL w Wilnie $\mathrm{z}$ pieczęcią wileńskiego sądu ziemskiego; B. Wróblewskich, RS, f. 16-92, k. 74

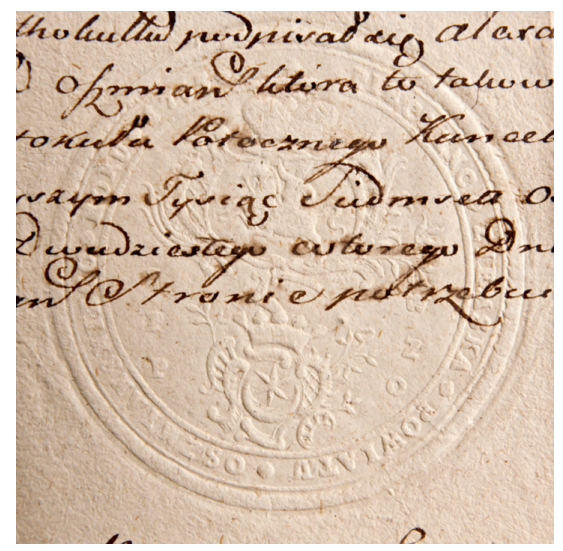

Il. 3. 1782 r., wypis z 1765 r. z pieczęcią oszmianskiego sądu ziemskiego; B. Uniwersytetu Wileńskiego, RS, f. 5-B2-265

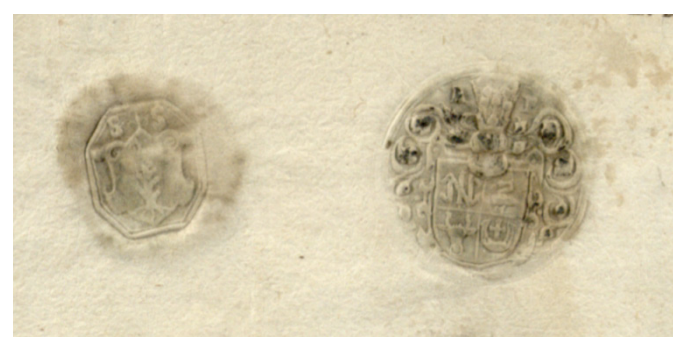

Il. 2. 1586 r., wypis z ksiąg oszmiańskiego sądu ziemskiego z pieczęciami sędziego i podsędka; B. Wróblewskich, RS, f. 16-77, k. 150

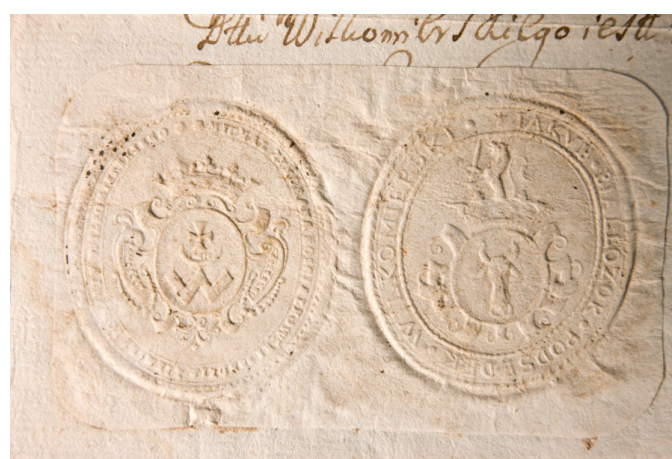

Il. 4. 1731 r., wypis z ksiąg wilkomierskiego sądu ziemskiego z pieczęciami sędziego i podsędka; B. Uniwersytetu Wileńskiego, RS, f. 5-A28-4975 